\title{
Communication
}

[Comunicação]

\section{Prevalence and identification of Salmonella spp. in water buffaloes from São Paulo State, Brazil}

[Prevalência e identificação de Salmonella spp. em búfalos do Estado de São Paulo, Brasil]

\author{
D.G. Silva ${ }^{1}$, A.M. Santana ${ }^{1}$, R.P. Maluta ${ }^{1}$, L.J.L. Pizauro ${ }^{1}$, P.A. Bernardes ${ }^{1}$, \\ G.V. Aquino ${ }^{1}$, N.C. Benincasa ${ }^{1}$, D.P. Rodrigues ${ }^{2}$, J.J. Fagliari ${ }^{1}$ \\ ${ }^{1}$ Universidade Estadual Paulista - Jaboticabal, SP \\ ${ }^{2}$ Fundação Oswaldo Cruz - Manguinhos, RJ
}

\begin{abstract}
Salmonella spp. are gram-negative bacteria and an important cause of economic losses in livestock besides being a zoonotic agent responsible for foodborne illness (Borrielo et al., 2012). There are two species of Salmonella: $S$. bongori and $S$. enterica (subdivided into six subspecies: arizonae, diarizonae, enterica, houtenae, indica and salamae), with more than 2,500 known serotypes. The infection of warmblood animal species is caused by several serotypes of $S$. enterica subspecies enterica (Strockbine et al., 2015).
\end{abstract}

Bovine salmonellosis is caused predominantly by S. enterica subspecies enterica serotype Dublin ( $S$. Dublin) and $S$. enterica subspecies enterica serotype Typhimurium ( $S$. Typhimurium), often associated with systemic infection and enteritis, respectively (Silva et al. 2008; Ávila et al., 2011).

Salmonella spp. have been reported worldwide in buffaloes, with prevalence rate between $1 \%$ to 25\% (Borrielo et al., 2012; Anwarullah et al., 2014; Yousif and Al-Hashimi, 2014, Hadimli et al., 2017), but the serotypes isolated from buffaloes are poorly characterized in some studies. The aim of this study was to investigate the occurrence of Salmonella spp. in fecal samples of buffaloes from São Paulo State, Brazil, and to identify the serotypes isolated.

A total of 116 rectal swab samples of Jafarabadi and Murrah buffaloes (water buffaloes), collected in triplicate, from six rural properties

Recebido em 30 de abril de 2017

Aceito em 24 de janeiro de 2018

E-mail: danisoulbr@yahoo.com.br located in Central, Midwest and Northeast of São Paulo State, Brazil, were examined. To evaluate the presence of Salmonella spp., rectal swabs were enriched in $10 \mathrm{~mL}$ of selenite cystine broth (CM0699, Oxoid), Muller-Kauffmann tetrationate broth (CM0343, Oxoid) and Rappaport-Vassiliadis broth (CM0866, Oxoid) and incubated at $37^{\circ} \mathrm{C}$ for $24 \mathrm{~h}$. The broths were then seeded on plates containing modified brilliant green agar (CM0329, Oxoid) and xylose lysine tergitol 4 (XLT4) agar (223420 and 235310, BD Difco) and incubated at $37^{\circ} \mathrm{C}$ for 24h. Colonies with morphologic characteristics of the genus Salmonella (Quinn et al., 2005) were inoculated in tubes containing triple sugar iron (TSI) (CM0277, Oxoid) and lysine iron agar (LIA) (CM0381, Oxoid) and incubated at $37^{\circ} \mathrm{C}$ for $24 \mathrm{~h}$. After biochemical confirmation, slide agglutination tests were performed using somatic and flagellar polyvalent Salmonella antiseras (Probac do Brasil). Positive samples in slide agglutination test were inoculated in tubes containing nutrient agar (CM003, Oxoid) and sent to the Laboratory of Enterobacteria of the Instituto Oswaldo Cruz - IOC/FIOCRUZ (Manguinhos, Rio de Janeiro, Brazil) for serotyping. The study was approved by the Animal Research Ethics Committee of Universidade Estadual Paulista (Unesp), Faculdade de Ciências Agrárias e Veterinárias, Jaboticabal - SP (protocol number 010885/08).

Of the 116 rectal swabs examined, eight samples $(6.90 \% ; 8 / 116)$ were positive for Salmonella spp. (Figure 1), characterized by four serotypes: $S$. Panama (50\%; 4/8), S. Agona (25\%; 2/8), S. 
Newport $(12.5 \% ; 1 / 8)$ and $S$. Saintpaul $(12.5 \%$; 1/8) (Figure 2). Of the eight positive samples of Salmonella spp., two samples $(25 \% ; 2 / 8)$ were isolated from selenite cystine broth, four samples $(50 \% ; 4 / 8)$ were isolated from MullerKauffmann tetrationate broth, one sample $(12.5 \%$; 1/8) was isolated from Rappaport-
Vassiliadis broth, and one sample $(12.5 \% ; 1 / 8)$ was simultaneous isolated from MullerKauffmann tetrationate broth and RappaportVassiliadis broth. All eight samples were isolated simultaneous from modified brilliant green agar and XLT4 agar.

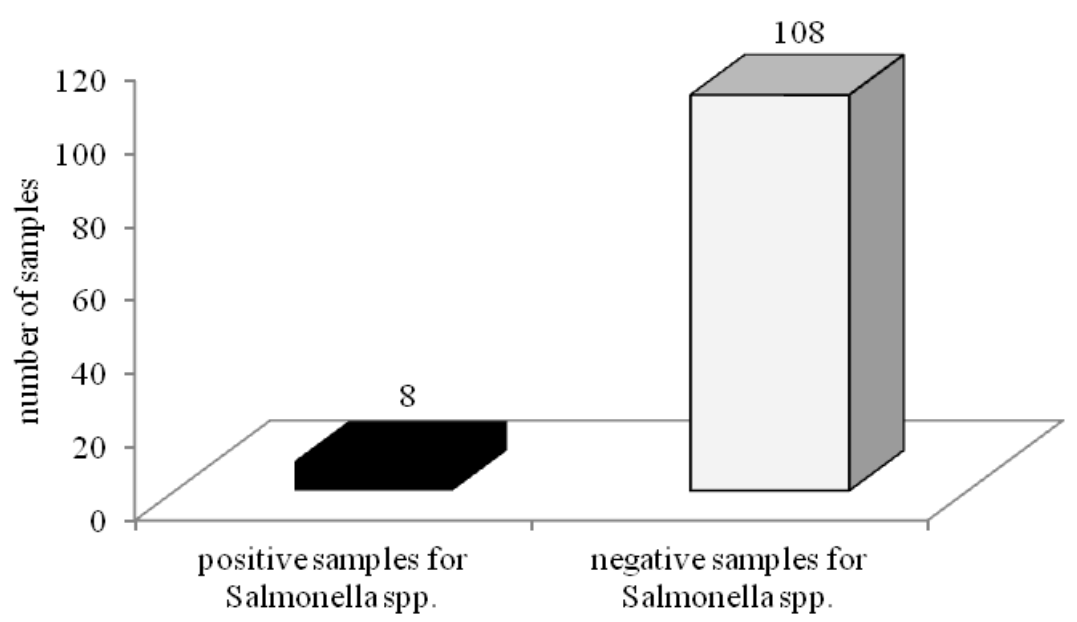

Figure 1. Number of rectal swab samples of water buffaloes from rural properties located in São Paulo State, Brazil, positive or negative for Salmonella spp.
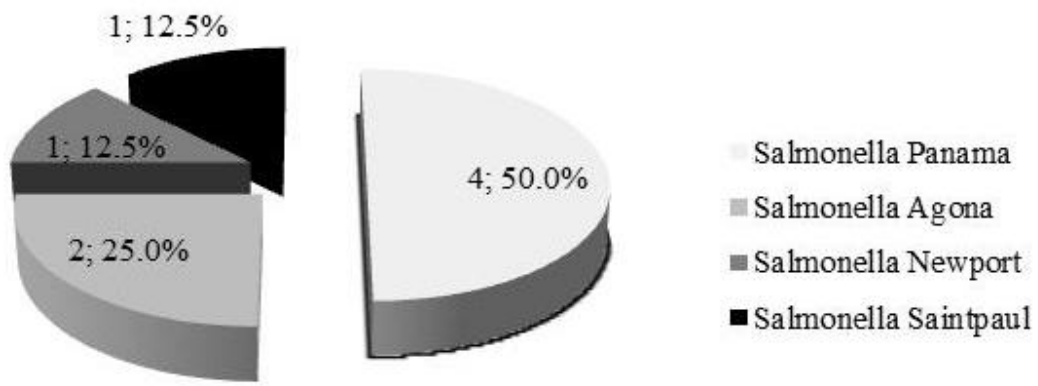

Figure 2. Salmonella serotypes isolated in rectal swabs samples of water buffaloes from rural properties located in São Paulo State, Brazil.

The serotypes $S$. Panama (n=4), $S$. Newport $(\mathrm{n}=$ 1) and $S$. Saintpaul $(n=1)$ were isolated from Murrah buffalo calves between 11 to 26 -day-old while $S$. Agona $(\mathrm{n}=2)$ were isolated from Jafarabadi lactanting buffaloes, both without clinical signs of salmonellosis.

Of the six rural properties evaluated, only in two farms $(33.3 \%$; 2/6) Salmonella spp. was not detected. According to IBGE data (Produção..., 2016), the Brazilian buffalo population in 2015 was 1,365,636 animals, and São Paulo State accounts for the third largest herd of the country, with 90,873 buffaloes.
However, in Brazil there are few studies about the prevalence of Salmonella in buffaloes and in none of these studies Salmonella spp. were detected (Ribeiro et al., 2000; Fortes, 2013), unlike the present study in which a prevalence rate of $6.90 \%$ was reported and four different serotypes were identified ( $S$. Panama, $S$. Agona, $S$. Newport and $S$. Saintpaul).

While bovine salmonellosis is caused predominantly by $S$. Dublin and $S$. Typhimurium (Silva et al. 2008; Ávila et al., 2011), many other serotypes have been isolated from buffaloes (Borrielo et al., 2012; Yousif and Al-Hashimi, 
2014, Hadimli et al., 2017), as also observed in the present study.

Salmonella spp. was more isolated in fecal samples from asymptomatic newborn buffalo calves $(75 \% ; 6 / 8)$. Adult buffaloes positive for Salmonella spp. $(25 \% ; 2 / 8)$ did not show clinical signs either, indicating the importance of asymptomatic animals as a source of infection to other animals and humans. Other important aspect of epidemiology of Salmonella infection in buffaloes is that in four farms $(66.7 \% ; 4 / 6)$ Salmonella spp. were detect. These results can be associated with the use of more than one selective enrichment broth (selenite cystine broth, Muller-Kauffmann tetrationate broth and Rappaport-Vassiliadis broth) and culture medium (modified brilliant green agar and XLT4 agar) for Salmonella isolation, as recommended by Fernandes et al. (2004).

The prevalence of Salmonella spp. in water buffaloes from São Paulo State was $6.90 \%$ and four different serotypes were identified: $S$. Panama, $S$. Agona, $S$. Newport and $S$. Saintpaul. Positive animals did not present clinical signs of salmonellosis indicating the importance of the asymptomatic animals as a source of infection to other animals and humans.

\section{ACKNOWLEDGMENTS}

To Fundação de Amparo à Pesquisa do Estado de São Paulo - FAPESP (process number: 2008/50388-7 and 2009/12350-0) and to Conselho Nacional de Desenvolvimento Científico e Tecnológico - CNPq (process number: 304117/2014-5) for granting financial support.

Keywords: Bubalus bubalis, enrichment broth, feces, Salmonella, serotype

\section{RESUMO}

O objetivo do estudo foi investigar a prevalência de Salmonella spp. em amostras de fezes de búfalos do estado de São Paulo, Brasil, e identificar os sorotipos isolados. Foram examinadas 116 amostras de suabes retais de búfalos das raças Jafarabadi e Murrah, coletadas em triplicata, em seis propriedades rurais localizadas nas regiões Central, Centro-Oeste e Nordeste do estado de São Paulo, Brasil. Para avaliar a presença de Salmonella spp., foram utilizados três diferentes caldos de enriquecimento (caldo selenito cistina, caldo tetrationado Muller-Kauffmann e caldo Rappaport-Vassiliadis) e dois diferentes meios de cultura (ágar verde brilhante modificado e ágar XLT4). Das 116 amostras de suabes retais examinadas, oito amostras $(6,90 \%$; 8/116) foram positivas para Salmonella spp., incluindo quatro sorotipos: S. Panama (50\%; 4/8), S. Agona (25\%; 2/8), S. Newport (12,5\%; 1/8) e S. Saintpaul (12,5\%; $1 / 8)$, todos isolados de búfalos sem sinais clínicos de salmonelose, indicando a importância dos animais assintomáticos como fonte de infecção para outros animais e seres humanos. Das seis propriedades rurais avaliadas, apenas em duas fazendas (33,3\%; 2/6) não foi detectada Salmonella spp. O uso de mais de um caldo de enriquecimento seletivo e de mais de um meio de cultura é indicado para o isolamento de Salmonella.

Palavras-chave: Bubalus bubalis, caldo de enriquecimento, fezes, Salmonella, sorotipo

\section{REFERENCES}

ANWARULLAH, M.; KHAN, J.A.; KHAN, M.S. et al. Prevalence of Salmonella and Escherichia coli associated with diarrhea in buffalo cows and calves. Buff. Bull., v.33, p.332336, 2014.

ÁVILA， L.G.; SILVA， D.G.; SATO, R.A.; FAGLIARI, J.J. Clinical evaluation of experimental Salmonella Typhimurium-infection in calves. Arq. Bras. Med. Vet. Zootec., v.63, p.1587-1590, 2011.
BORRIELO, G.; LUCIBELLI, M.G.; PESCIAROLI, M. et al. Diversity of Salmonella spp. serovars isolated from the intestines of water buffalo calves with gastroenteritis. BMC Vet. Res., v.8, p.1-9, 2012.

FERNANDES, A.C.; BERCHIERI JR., A.; OLIVEIRA, G.H.; PEREIRA, G.T. Evaluation of culture mediums for the isolation of Salmonella. Ars Vet., v.20, p.330-337, 2004. 
FORTES, T.P. Isolamento de Salmonella sp. em ruminantes abatidos em frigorífico de Pelotas, $R S$ e avaliação da suscetibilidade dos isolados a antimicrobianos. 2013. 60f. Dissertação (Mestrado em Medicina Veterinária) - Faculdade de Veterinária, Universidade Federal de Pelotas, Pelotas, RS.

HADIMLI, H.H.; PINARKARA, Y.; SAKMANOĞLU, A. et al. Serotypes of Salmonella from isolated feces of cattle, buffalo, and camel and sensitivities to antibiotics in Turkey. Turk. J. Vet. Anim. Sci., v.41, p.1-6, 2017.

PRODUÇÃO da pecuária municipal 2015. Rio de Janeiro: IBGE, 2016. Available in: <http://www.ibge.gov.br/home/estatistica/econo $\mathrm{mia} / \mathrm{ppm} / 2015 /$ default_ods_brasil.shtm $>$. Accessed in: 29 Sep. 2016.

QUINN, P.J.; MARKEY, B.K.; CARTER, M.E. et al. Microbiologia veterinária e doenças infecciosas. Porto Alegre: Artmed, 2005. 512p.
RIBEIRO, M.G.; LANGONI, H.; JEREZ, J.A. et al. Identification of enteropathogens from buffalo calves with and without diarrhoea in the Ribeira Valley, State of São Paulo, Brazil. Braz. J. Vet. Res. Anim. Sci., v.37, p.159-165, 2000.

SILVA, D.G.; SILVA, P.R.L.S.; FAGLIARI, J.J. et al. Clinical evaluation of experimental Salmonella Dublin infection in calves. Arq. Bras. Med. Vet. Zootec., v.60, p.251-255, 2008.

STROCKBINE, N.A.; BOPP, C.A.; FIELDS, P.I. et al. Escherichia, Shigella, and Salmonella. In: JORGENSEN, J.H.; PFALLER, M.A. (Eds.). Manual of clinical microbiology. 11.ed. Washington: ASM Press, 2015. p.685-713.

YOUSIF, A.A.; AL-HASHIMI A.D.M. Distribution of Salmonella species in buffaloes in some middle governorates of Iraq. Buff. Bull., v.33, p.337-349, 2014. 